\author{
OLEXANDR HORBAN, \\ Borys Grinchenko Kyiv University (Kyiv, Ukraine) \\ e-mail: o.horban@kubg.edu.ua,ORCID 0000-0003-2321-5963 \\ MARIA MALETSKA, \\ Borys Grinchenko Kyiv University (Kyiv, Ukraine) \\ e-mail: vernaya.lynx@gmail.com, ORCID 0000-0003-3123-9500
}

\title{
BASIC HERMENEUTIC APPROACHES TO INTERPRETATION OF VIDEOGAMES
}

\begin{abstract}
The article is devoted to the videogame interpretation and the basic hermeneutic approaches to interpretation of videogames. Videogames are complex contemporary phenomenon that differs from other media with its interactivity and specific relations between game and player. The absence of common methodology, especially hermeneutic methodology, makes it hardly possible to deal with the interpretation of videogames and understanding of specific features of interpretation of games by player, spectator and developer. Key concepts of hermeneutics important for the solving the tasks of the article are described. The result of given research is the distinguishing of four basic hermeneutic approaches according to the core concept of understanding the videogame phenomenon: 1) game hermeneutics / hermeneutics in general - without specific core concept (videogame is interpreted without consideration of its interactivity); 2) ludo-hermeneutics - with the game as core concept (videogame is interpreted as a game, but the game is prioritized above player); 3) procedural hermeneutics - with rules as core concept (videogame is interpreted as procedural system; this approach does not consider the importance of player's actions and possibility of breaking rules); 4) real-time hermeneutics - with interactivity as core concept (videogame is interpreted as interactive system; this approach states the particular role of player and distinguishes it from the role of spectator). The detailed characteristics of mentioned approaches are given. The plurality of interpreters of videogames is mentioned. Not only players, who interpret games with the view of winning, but also spectators and developers can interpret videogames differently because of different positions and influence on interpretation of each other. In conclusion, uncovered field of interpretation and aspects disregarded by previous researches on hermeneutic interpretation of videogames are described.
\end{abstract}

Key words: videogame; hermeneutics; ludo-hermeneutics; procedural rhetoric; procedural hermeneutics; real-time hermeneutics; interpretation.

\section{Introduction}

Contemporary world has become more complicated because of appearing of unusual combinations of usual things of human life. Videogames are vivid example of such phenomena; they may consist of plot, video- and audio-content, involve players into complex social interaction or they simply can be a piece of story given to player in interactive form. There are also games without any plot like Tetris, virtual versions of puzzles, Sudoku etc. Although they all are different, they form the generality which requires specific approaches to analyzing and understanding.

Videogames are not only a way of entertainment, some of them contain messages that are perceived by player. These messages also might remain misunderstood or unnoticed. Modern games may contain information about politics and economics, may simply advertise some products or tell deep stories about human life. They also may be created for education, communication or creativity, and understanding of them often varies depending on the purpose of creation. There is a lot of questions related to the way of communication between game and player and relation between specific features of videogames and the ability to understand all messages hidden by authors.
Videogames are different from other media, particularly because of the specific role of player. The player is not only an interpreter, as he is in case of interaction with literary works or films, he is an actor in the virtual world of the game. The idea of interactive media in general is also not new, however, namely videogames were the phenomenon which formed a possibility for communication and cooperation between players inside the game world, for creation of virtual societies with their own politics, economics, ethical rules and moral norms, which separates them from all other media. They create a plurality of worlds existing changing with player's actions. This plurality is perceived and somehow interpreted by all who participate in the process of playing.

Hermeneutics is a theory, methodology and practice of interpretation. It raises questions of possibility of understanding and sense-making in communication with other people and during interaction with texts, different phenomena. Hermeneutic research of videogames is important at least to analyze how videogames change understanding and how the role of interpreter changes in case of videogames. It can also be helpful when we speak about the dialogue of game developers and players. This dia- 
logue often happens in other way then the dialogue with writers, film directors etc. For videogames, especially multiplayer games, feedback given by players is extremely important, it shows the level of understanding of product by users and provides changes in games. You cannot write to a writer with opinion about things that should be changed in a book; at the same time, many game developers ask players to write what changes they want to see or what problems they found in the process of playing. Such possibility has established a specific form of communication and raised additional questions of mutual understanding.

There are several approaches to hermeneutic interpretation of videogames. However, they give different answers to questions of relations of game and player and emphasize different aspects of understanding. The absence of common methodology, especially hermeneutic methodology, makes it hardly possible to deal with understanding of the whole phenomenon of videogames.

Thus, the purpose of our research is to describe the basic hermeneutic approaches to interpretation of videogames and to delineate the field of understanding which is not covered by these approaches.

\section{Methods}

First of all, general scientific methods - analysis, synthesis, classification - were used in the study disclosed in the article. In addition, hermeneutic methodology was used. Among other, there were used comparative method, system and typological methods to describe the difference between approaches that are applied namely within the framework of the game studies and to form the complex system of analyzed approaches. The problem-chronological approach allowed systematic consideration of existing hermeneutic approaches and outlining aspects of interpretation left out of an account.

\section{Results and Discussions}

Hermeneutics can loosely be defined as the theory or philosophy of the interpretation of meaning (Bleicher, 1980: 9). Having ancient Greek roots (Palmer, 1969) and being established as an art of Bible interpretation, it have developed into the theory and methodology of interpretation. At the beginning the problem of interpretation was connected with understanding of texts, and, especially, Bible texts. Today, not only documents, literary texts and scriptures can be called texts, but also symbols, rituals, practices and customs, myths, structures of power, kinship and social set-ups, and many more besides (Demeterio, 2001). All human history, communication, phenomena of culture, economics, politics, and everyday life in view of hermeneutics consist of texts.

The realization that human expressions contain a meaningful component, which has to be recognized as such by a subject and transposed into his own system of values and meanings, has given rise to the "problem of hermeneutics": how this process is possible and how to render accounts of subjectively intended meaning objective in the face of the fact that they are mediated by the interpreter's own subjectivity (Bleicher, 1980: 9). This problem unfolds at different levels: at the linguistic level (how meanings of words change, how words can be understood and translated etc.), at the historical level (understanding of phenomena in different historical circumstances and with regard to different historical environment), at the psychological level (how human consciousness can perceive the information), at the personal level (understanding of a personal significance of texts).
Philosophical hermeneutics focuses on the understanding as more subjective phenomenon. It describes intersubjective communication and subjective perception with its own specific categories. There are key concepts of hermeneutics that should be delineated in our research. One of the central hermeneutic concepts, defining of which is important for further analysis, are "horizon" and, then, "fusion of horizons". These concepts were introduced by H.-G. Gadamer to conceptualize understanding. The horizon is the range of vision that includes everything that can be seen from a particular vantage point. With this concept we can speak of narrowness of horizons, of the possible expansion of horizons, of the opening up of a new horizons, and so forth (Gadamer, 2004: 301). Understanding is always the fusion of these horizons supposedly existing by themselves (Gadamer, 2004: 305).

The possibility of fusion of horizons also states the problem of reinterpretation. It is thoroughly described in the following fragment: "The hermeneutic problem may become clearer to us when we recall the odd experience of reading a book for a second time. Such a re-reading often opens up a new reception of text. We may discover something new, something different in the text, and we may say now we see the book with different eyes. Yet it apparently the same book we see, and it is through our own eyes we see that we see. So what is different? What has changed? Our perspective has changed; that is the way in which we look at the text or a work of art. In our case, the way we look at our book has changed radically, yet nonetheless we now see the text differently ... Understanding then comes about when these two realities meet: the reality of the reader and the reality of the text" (Jeanrond, 1991: 1). This fragment shows one of the situations of the fusion of horizons, describing it as the process of meeting of two "realities". The alternative interpretations appear not only because of changes of the reader; reinterpretation is different from the first-time interpretation because of previous experience of fusion of horizon. Previous understanding in general becomes a part of horizon for further interpreting.

Another hermeneutic concept important for our research is the "hermeneutic circle". Formulated variously in different theories of hermeneutics, the circle generally describes how, in the process of understanding and interpretation, part and whole are related in the circular way: in order to understand the whole, it is necessary to understand the parts, while to understand the parts it is necessary to have some comprehension of the whole. Whereas in earlier hermeneutics the circle is used primarily to describe the understanding of texts, in the hermeneutic philosophy of Martin Heidegger and Hans-Georg Gadamer the circle becomes a fundamental principle of man's understanding of his own nature and situation. Understanding, and with it the hermeneutic circle, becomes a condition for the possibility of human experience and inquiry (Hoy, 1982: 7).

The great attention in hermeneutics is paid to problems of language, however, in case of videogames problems of the philosophy of language are the same as in case of other texts. There are general difficulties in translating, word use etc., but we cannot mention something unique about the use of languages in videogames except the fact that there are non-verbal videogames, games without words used in game process. In such games language is used only in main menu and is not involved in gameplay. The plot of these games is constructed with the help of signs, sound, visual and audial components. Here 
we can mention "GRIS"1, "Journey"2, "LIMBO"3 as examples of videogames without textual part at all. The existence of games with such absence of the text accentuate the importance of understanding the sense-making and interpretation of games.

The example of non-textual videogames shows one of the various combinations of different ways of representing a plot and ideas. Videogames presented a conflict between narrative and gameplay, since classical narrative tends to fixed pre-determined structures and gameplay is based on interactivity. Modern games try to address this issue though branching, non-linearity and stories with multiple endings which depends on the player choices (Yolanda, 2016: 7). Sometimes it might be difficult to understand how videogames may belong to one category, but they have some common features, distinguishing of which improves understanding of the specifics of interpretation.

There is still no generally used definition of videogame. However, there are several common approaches of defining and understanding the nature of videogames (Horban, Maletska, 2018). These approaches correlate with hermeneutic approaches to videogame interpretation. We divided our research into parts dedicated to approaches with different core ideas.

Game hermeneutics / hermeneutics in general - without specific core concept. Talking about approaches to videogame interpretation, we should start with a general approach to game interpretation. It was mentioned by Jonne Arjoranta and described as following: "Game hermeneutics is a more traditional type of hermeneutics, interested in games as objects that need to be interpreted in certain historical contexts. It would be useful, for example, when looking at how the character of Mario has changed from the early days of Super Mario Bros. to the present" (Arjoranta, 2015: 59).

Disadvantages of such approach are obvious from characteristics that separate videogames from other media. It leaves out of an account the specific role of a player, interaction between player and game, game mechanics, features of different genres and settings etc.

However, there are some videogame genres where games may be interpreted in such way. Some visual novels need to be interpreted in certain historical, social context, but without paying much attention to the game nature of videogames. The term visual novel represents a multimedia game which has all the multimedia's elements like text, backgrounds, characters, music, sounds and it has interaction with the player (Bashova, Pachovski, 2013). Visual novels have pure gameplay part and their main purpose is to reveal some story with one or a number of endings.

The branching of the story is typical for the visual novel, because there are decision points in the game where the player is expected to make a decision about the next step of the story. Based on the chosen option, the player will reach a certain end of the story. This way, when the player finishes the game, he/she is motivated to play it again in order to see the other (alternative) ends of the story. Based on how many decision points are in the visual novel, it increases its alternative story's ends as well as its comp-

\footnotetext{
1 Developed by Nomada Studio, produced by Devolver Digital, 2018.

2 Developed by Thatgamecompany, produced by Sony Computer Entertainment, Annapurna Interactive, 2012.

3 Developed by Playdead, produced by Microsoft Game Studios, Playdead, 2010.
}

lexity (Bashova, Pachovski, 2013). Thus, the only way of interaction proposed to player in games of this genre is a choice of several options. The more complicated the plot is and the more massive the novel is, the number of possible options increases. The closeness to interactive books and books in general is laid in the name of this genre - they are novels first of all, so they can be interpreted as objects in some contexts. There is usually no need in understanding of game mechanics while playing a visual novel, the story (with or without changes with player's choices) is simply told to the player. The role of the player in such games reduces to the role of passive or active reader who has little freedom of actions.

This genre often describes a love story. "NekoPara"4, series of visual novels about a life of a young man in a fictional world is an example of the visual novel without choices at all. So, it can be simply read by the player and it is understood like a graphic novel.

Ludo-hermeneutics - the game as core concept. The second considered approach is based on the general concept of game. Many definitions and videogame researches mention that videogames are games first of all. Examples can be found in researches by Gonzalo Frasca (1999), Nicolas Esposito (2005), Miguel Sicart (2009), in work "Understanding Video Games: The Essential Introduction" (2012). According to them, all videogames are more or less games, they need player at least as a spectator who starts the process of play and is involved in it to some extent: as passive interpreter of information given in game, similar to reader or film viewer, or as "spectauthor" (Nardone, 2017: 52) who changes videogame or acts as co-creator.

Studies of videogames on the base of game concept usually start with ideas of Johan Huizinga. In "Homo Ludens" he describes the play-element in culture and specifics of games as a culture basis. He marks several characteristics of play separating them from all other human activities. The first main characteristic of play is that it is free, is in fact freedom: "Play to order is no longer play: it could at best be but a forcible imitation of it. It is never imposed by physical necessity or moral duty. It is never a task". A second characteristic is disclosed in the fact that play is not "ordinary" or "real" life. It is rather a stepping out of "real" life into a temporary sphere of activity with a disposition all of its own. Play is distinct from "ordinary" life both as to locality and duration. The third main characteristic of play: its secludedness and limitedness: "It is "played out" within certain limits of time and place. It contains its own course and meaning. Play begins, and then at a certain moment it is "over". It plays itself to an end. While it is in progress all is movement, change, alternation, succession, association, separation. But immediately connected with its limitation as to time there is a further curious feature of play: it at once assumes fixed form as a cultural phenomenon. Once played, it endures as a new-found creation of the mind, a treasure to be retained by the memory. It is transmitted, it becomes tradition. It can be repeated at any time, whether it be "child's play" or a game of chess, or at fixed intervals like a mystery. In this faculty of repetition lies one of the most essential qualities of play. It holds good not only of play as a whole but also of its inner structure" (Huizinga, 1949: 8-10). Ludology as a part of game studies focused on videogames as games with additional features arose from J. Huizinga's work.

\footnotetext{
${ }^{4}$ Developed and produced by NEKO WORKs, 2014-2019.
} 
J. Huizinga's concepts were mentioned by H.-G. Gadamer in his "Truth and method". Play formed an important part of his hermeneutics in general. He also developed the game concept with new characteristics and shifted the focus of the understanding from play as activity to play as independent phenomenon. H.-G. Gadamer improved an idea of relations between player and game, adding the differentiation of one who plays and who does not play and mentioning the changes in interpretation connected with this differentiation: "Thus it can be said that for the player play us not serious: that is why he plays. We can try to define the concept of play from this point of view. What is merely play is not serious. Play has a special relation to what is serious ... Seriousness is not merely something that calls us away from play; rather, seriousness in playing is necessary to make wholly play. Someone who doesn't take the game seriously is a spoilsport. The mode of being of play does not allow the player to behave toward play as if toward an object. The player knows very well what play is, and that what he is doing is "only a game"; but he does not know what exactly he "knows" in knowing that" (Gadamer, 2004: 102-103).

H.-G. Gadamer is considered the first ludologist. More interested in "games themselves" than in the player, he suggests that the playing of a fame is a way for "an activity to become a work" and thus gain independence from the subject engaged in it (Leino, 2010: 71). It can also be proved with the following H.-G. Gadamer's statement: "The players are nor the subjects of play; instead play merely reaches presentation through the players ... The real subject of the game (this is shown in precisely those experiences in which there is only a single player) is not the player but instead the game itself" (Gadamer, 2004: 106).

Whether Gadamer is right or not, he is close to the position in game studies where the relationship between player and the game is defined by the gameplay and mechanics, and only intermittently by the player's observations of the mimetic, representational aspects of the game. This position has sometimes been construed as a focus on the formal aspects of play, but it would be more accurate to see it as an emphasis on the player as a part of the game system, an agent partly definable by the role the game affords, and as a condition framed by the game's affordances and therefore as an integrated part of game (Wolf, Perron, 2014).

This approach considers player as actor, who has more important role to play in videogame than simple observing. However, understanding videogame as an unchangeable system where player exists as a part of a game excludes many genres from the possibility of interpretation. This approach also understands the player as not as subject, but as object bound with game world without any possibility to change it or to act freely. It prioritize the game above player, partially missing the fact that game cannot exist and cannot be interpreted without player's participation.

This approach laid the foundation for forming of the next approach described in our article.

Procedural hermeneutics - rules as core concept. Some researchers focus attention on one of the important parts of games - the system of rules. This includes both rules of interaction as external rules and rules of game world as internal, artificial rules: "...video games are two rather different things at the same time: video games are real in that they are made of real rules that players actually interact with; that winning or losing a game is a real event. However, when winning a game by slaying a dragon, the dragon is not a real dragon, but a fictional one. To play a video game is therefore to interact with real rules while imagining a fictional world and a video game is a set of rules as well a fictional world" (Juul, 2005). Games are thus suggested to be both systems of rules and fictions (Bateman, 2011: 14).

Ideas of importance of rules and considering videogames as procedural systems were developed by lan Bogost. He argues that the rules shape not only the process, but also the meaning of videogames: "The rules do not merely create the experience of play - they also construct the meaning of the game. That is to say, the gestures, experiences, and interactions a game's rules allow (and disallow) make up the game's significance. Video games represent processes in the material world - war, urban planning, sports, and so forth - and create new possibility spaces for exploring those topics. That representation is composed of the rules themselves" (Bogost, 2008: 121).

I. Bogost connects procedurality with technical processes of using rules by hard- and software. His term "procedural" refers to the defining ability of computer or some other apparatus to execute written rules. He connects procedurality with the processor as the "brain" or "heart" of a computer and names it "is the principal value of the computer, which creates meaning through the interaction of algorithms" (Bogost, 2008: 122). For his practice of game understanding he gives the name "procedural rhetoric" and describes how ideas and arguments are given through the procedure of play. He even describes the educational process based on videogames with means of procedural rhetoric. His methods of understanding are proposed as means of finding and explaining the hidden ways of thinking that may influence on the player's behavior and attitude towards the different phenomena of human life. On several examples he shows how videogames may serve for hidden representation of policy positions, moral imperatives, describe real situations. He uses his practice to explain and, moreover, to interpret the facts and information given in videogames.

However, the rules should not be absolutized. In case that rules are considered the central category that proves the difference of videogames from other media and arts, videogames appear reduced to simple rule-based structure and the role of player and play in general is negated. Miguel Sicart in his critique of proceduralism focuses attention on risk of such reduction. He argues against $I$. Bogost's conception of procedural rhetoric and branch of procedural hermeneutics that have grown up from it: "Against procedurality an army of players stand and play, breaking the rules, misunderstanding the processes, appropriating the spaces of play and taking them somewhere else, where not even the designer can reach. Against proceduralism is a player who wants to play" (Sicart, 2011). Here attention is paid to the role of the player as uncontrolled force that can break the rules. Players tend to be creative and reflective, even with games that do not afford them control over the rules (Sicart, 2009: 9).

The existence of such critique of proceduralism gave a grounding for the development of procedural hermeneutics as methodology based on procedural rhetoric but with significant modifications. The principles of procedural hermeneutics as independent method were presented by Alexey Salin. He developed these principles on base of I. Bogost's researches as an attempt to find middle position between proceduralism and its critique. He states four principles that reveals the essence of procedural hermeneutics:

1. A player cannot interpret values embodied in procedures of a computer game independently of a visual, audial and/or verbal content of the game. Video games are multimedia.

2. Interpretations of a computer game are valid only if 
they are compatible with an interpreter's ability to interpret the game. But this does mean neither that one should first understand a game to play it nor that processes of understanding and playing must proceed contemporaneously. There may be multiple temporal modes of playing-understanding relationship.

3 . The understanding of a video game can be described as a process that passes through two spirals, a narrative one and a hermeneutic one. Narrative spiral builds up a game's meaning while hermeneutic spiral introduces a game's significance. Narrative spiral builds up an intersubjective gameworld, that is common for any possible player and where different types of actors are defined by their relations to other actors, whereas hermeneutic spiral does not simply tell something about gameworld but ties it somehow to the real world. This cycle is a specific variation of hermeneutic circle. Both cycle consist of circles of interpretation, and together they also form a new hermeneutic circle, where a part is previous understanding of both cycles and the whole is the videogame in general. It depends on a player's social position how she interprets a game and whether she interprets it at all.

4. Understanding a message of a video game requires understanding of the logic of the program confronting the player while she is playing. This logic may sharply differ in many ways from what we consider to be a human logic. Since understanding a game has a dialogue form, it is claimed that this understanding requires communication with non-human Otherness (Salin, 2018: 7-8).

As we can see from the above principles, procedural hermeneutics in general pays more attention to the role of player, but it centers on the interaction with rule-based non-human Otherness - computer or other hardware used for playing videogame. Although it considers the role of player, it also ignores the possibility of player's attempts to break game rules.

In some cases videogame is aimed at breaking the rules or going beyond the limits of the game process. Modern game developers build their game with taking into consideration the fact that player might want to confront not the fictional enemy, but all videogame in general. There are several examples of such confrontation in different genres.

One of the newest examples of described situation is "Doki Doki Literature Club!" 5 . Pretending to be a simple visual novel with possibility of influence on the plot through the choices in poetry writing, it transforms into psychedelic horror after one of the plot twists. The game developers made different courses of events for different variants of possible rule-breakings. Player may delete characters of the game in each acts of game and it will lead to the changes in game process and game behavior. Changes in files of game also changes the sayings of game characters - they "understand" that player tried to break the rules and make comments about it. These actions are not inevitable or compulsive for the player; however, the developers accounted possible player's desire to break the game process or to examine game files that are usually compiled or hidden to be inaccessible for player.

With this example we can see that the procedural hermeneutics does not include the case when player understands game logic and rules but cannot act in agreement with them. It means that, taking into account the player as the subject of communication and the actor, it considers

${ }^{5}$ Developed and produced by Team Salvato, 2017. the player as subject who accepts rules as a default or misunderstands them. The desire to ruin game or get the "bad" ending is understood as invalid interpretation.

Real-time hermeneutics - interactivity as core concept. Another way of understanding videogames is based on the dynamics and interactivity as the most important features distinguishing them from other media. The term "real-time hermeneutics" was firstly used by Espen Aarseth during the analysis of methodological approaches to game studies: "Game analysis is not just a critical / theoretical practice; gamers do it all the time. The primary objective / meaning of most games, how to play well and win, demands an analytical approach. In order to progress through the learning stages of a game, the player must explore various strategies and experiment with different techniques. This kind of pragmatic analysis could be said to be present in the consumption of other genres also, but non-academic viewers or players do not regard their engagement with a new literary or cinematic work as a learning process, which every player of a new game must and does. While the interpretation of a literary or filmatic work will require certain analytical skills, the game requires analysis practiced as performance, with direct feedback from the system. This is a dynamic, real-time hermeneutics that lacks a corresponding structure in film or literature" (Aarseth, 2003).

The concept of real-time hermeneutics had further development in works of Jonne Arjoranta. According to him, the real-time hermeneutics is more concerned with the processes of interpretation that are active when the player plays. It focuses on interaction between player and game and sense-making that is possible because of this interaction. He also mentions the procedurality as a characteristics of videogames, however, pays less attention to it than researchers that work with procedural hermeneutics and methodology. Instead of it, he focuses on interactivity and temporality as characteristics related to real-time hermeneutics. In J. Arjoranta's research, different types of "real time" are used to describe interaction between game and player. He also mentions different concepts of time as marks of interaction: play time (time span taken to play a game); fictional time (the time that progresses within a game); narrative time (time of narrating the story); story time (time within the story); dead time (time in games that is experienced as dull, repeating and not entertaining). $\mathrm{He}$ involves temporality to explain Aarseth's idea of formation of dynamic hermeneutics and shows inter-relation between the speed of interaction and specifics of interpretation: "There are different speeds of interactive, which may still be seen as happening in real-time - just not very quickly" (Arjoranta, 2011: 7). This approach cannot be considered as temporal hermeneutics because of explanatory meaning of the different concepts of time. They all are used to represent quantitative criteria of interactivity, experience or perceived information.

E. Aarseth also states important characteristics of videogames that were disregarded by J. Arjoranta. They both relate to the figure of the player. First characteristic shows the difference between the interpretation of videogames by the player and the researcher. The main task of the player is to win or to get a desired result from the game process; the view of the player differs from the view of researcher or spectator.

Uncovered field of interpretation. Mentioned hermeneutic approaches cover the most part of the videogame phenomenon. They have formed the ground for deep analysis and developed the methodology for researches 
on the sense-making and interpretation of videogames. However, several ideas important for game studies were uncovered by these approaches.

1. The idea of difference of view of player and nonplayer. This idea was firstly mentioned by H.-G. Gadamer and, after a while, transformed by E. Aarseth. According to H.-G. Gadamer, the attitude of a player towards a play is particularly serious even if the play is an entertainment. But the person who is not involved in playing may consider it not serious and spoil the game with such understanding of a game. E. Aarseth mentioned the difference between the interpretation of spectator and interpretation of player. The player interprets the game with the aim to win or to achieve the desired goal. Such interpretation is impossible in case of other media. We can analyze a book or a film, but we do not analyze them with such pragmatic purpose. This idea was described, but was not conceptualized. It is important to delineate this difference, though. One of the phenomena that is excluded from the process of comprehensive understanding because of the absence of hermeneutic conceptualization is Let's Play phenomenon. Let's Plays are captured videos, texts or screenshots, or all of them, produced by player to share their experience. Let's Plays are often uploaded to video sharing websites where one can subscribe to the Let's Player, leave comments and feedback and message the Let's Player privately, such as YouTube and Twitch (Fjællingsdal, 2014: 11). They provide communication between players, player and spectators and even player and developers. The interpretation of the game may change when it is played by the player, seen in Let's Play form, seen during the process of interpersonal communication etc. Player who is a producer of Let's Play shows his opinion and his interpretation and, thus, impacts on spectators. Let's Play spectators are also able to impact on player's interpretation with their comments, reactions and responses. This communication is based on the process of playing videogames and can be considered as particular case of interpretation with involving more than one subject.

2. Mentioned hermeneutic approaches do not analyze an interaction between player and developer. The possibility of communication with the developers also differs videogames from other media. It influences on interpretation of a game process, especially if we talk about multiplayer games which are in the process of constant changes. Game developers need feedback to understand how players interpret their games and how players would like to change games for better. Because of it the understanding occurs at different levels and gives different results. Player interprets game in usual way with the aim to win, and, at the same time, player analyzes advantages and disadvantages of game process, problems occurred in process of playing, disadvantages of mechanics, localization, graphic bugs etc. So, player can be considered a non-scientific researcher who interprets videogames in doubled way, and developers are specific subjects of game interaction who establish rules, provide and regulate their further changes. Reinterpretation of videogames by developers in process of updating according to feedbacks of players and understanding these feedbacks, changes of the meaning of videogames after the communication between player and developer for both of them should also be analyzed within hermeneutic approaches.

3 . The process of reinterpretation and the phenomenon of replayability also remain undiscovered. Contemporary videogames are created with the need to be replayed to be completely understood. For example, in "Pathologic" 6 the third game plot ("the path of Changeling") is available only after finishing the first ("the path of Bachelor") or the second ("the path of Haruspex"). In so-called "Souls" series - "Dark Souls"7, "Dark Souls II"8 and "Dark Souls III"9 some equipment and new items may be obtained only during the second playthrough, so-called "new game+". These items may also change interpretation of the game because they add new information about the game world or new possible game mechanics.

4. Mentioned hermeneutic approaches do not consider possibility of player's desire to break game rules or to spoil the game process in general. Although there are games that allow player to change game elements, presented approaches cannot describe the situation in which player goes beyond game limits, so it is not possible to provide understanding how the player interprets the game in this case.

As we can see from above analysis, in connection with videogames the problem of hermeneutics transforms as follows: how videogames are interpreted by player and how their interpretation differs from interpretation of other texts. Videogames embody and represent the hermeneutic circle in its broad sense. To understand the whole game, player should learn to understand different parts of game: game mechanics, rules of interaction and possibility of breaking them, connections between single actions and their results etc. And understanding of parts forms general understanding of the game as an integrated phenomenon. Interpretation of basic parts and the integrity formed by them is particularly important for player to interpret the game - and to find the way to win.

\section{Conclusions}

Videogames are complex phenomenon which requires specific methods of analysis and interpretation. Hermeneutic approaches represented in this article cover the most part of understanding of videogames, however, there still are perspectives for further researches. We analyzed four basic approaches to interpretation of videogames and delineated their core concepts. Their methods and the way of interpretation correlate with the concepts: general hermeneutic approach interprets videogames close to narratives, ludo-hermeneutics considers videogames as games first of all and builds the understanding on this ground; for procedural hermeneutics videogames are systems of rules, which reduces them strongly; in case of real-time hermeneutics, videogames are considered as specific phenomenon with interactivity in its core.

All mentioned approaches center on games and pay less attention to the figure of player. The player is an interpreter that is different from reader or spectator because of possibility of interaction and the existence of specific purposes: to win or achieve a desired goal. Thus, the process of understanding of a videogame is multiaspect. It changes with the change of the position: interpretation of player, spectator and developer of a videogame vary widely, but they all are related to one phenomenon; their fundamental difference lies not only in difference of

\footnotetext{
${ }_{6}^{6}$ Developed by Ice-Pick Lodge, produced by Devolver Digital, G2 Games, Brigades, Frogster Interactive, 2005.

${ }^{7}$ Developed by FromSoftware, produced by FromSoftware, Bandai Namco Entertainment, 2011.

${ }^{8}$ Developed by FromSoftware, produced by FromSoftware, Bandai Namco Entertainment, 2014.

${ }^{9}$ Developed by FromSoftware, produced by FromSoftware, Bandai
} Namco Entertainment, 2016. 
horizons of understanding, but also in significant difference between the purposes of interpretation. The situation of breaking the game is also insufficiently studied. Videogames are unique among other media because of possibility to influence on the changes in game development or to transform game files / improve the game manually. It is impossible to change the written book or produced film in such way, but in case of videogames player often has such opportunity. The communication with game developers is also specific situation of understanding and interpretation. That is why the role of subject of videogame interpretation should be researched deeply in further studies and researches on hermeneutics of videogames should be continued.

\section{REFERENCES}

Bleicher, J. (1980). Contemporary hermeneutics: Hermeneutics as method, philosophy, and critique. London: Routledge \& Kegan Paul.

Palmer, R. E. (1969). Hermeneutics: Interpretation Theory in Schleiermacher, Dilthey, Heidegger, and Gadamer. Northwestern University Press.

Demeterio, F.P.A. III. (2001). Introduction to Hermeneutics, Diwatao. 1(1): 1-9.

Gadamer, H.-G. (2004). Truth and method. Second revised edition. Translation revised by Joel Weinsheimer and Donald $g$. Marshall. New York: Continuum.

Jeanrond, W. G. (1991). Theological Hermeneutics Development and Significance. Basingstoke; London: Macmillan.

Hoy, D. C. (1978). The critical circle: literature, history, and philosophical hermeneutics. Berkeley: University of California Press.

Yolanda, M. W. (2016). Procedural plot generation in videogames to extend the player's agency in narrative (Bachelor's thesis). Departament d'Enginyeria i Ciència dels Computadors, Universitat Jaume I, Castelló de la Plana, Valencia, Spain.

Horban, O., \& Maletska, M. (2018). Basic approaches to the definition of the concept of "videogame" as an element of modern scientific discourse. Skhid, 3(155), 29-33. doi: http://dx.doi.org/ 10.21847/1728-9343.2018.3(155).139675.

Arjoranta, J. (2015). Real-Time Hermeneutics Meaning-Making in Ludonarrative Digital Games (PhD thesis). The Department of art and Culture Studies, University of Jyväskylä, Jyväskylä, Finland.

Bashova, K., \& Pachovski V. (2013). Visual novel. Unpublished. https://doi.org/10.13140/RG.2.1.5007.6405.

Frasca, G. (1999). Ludology Meets Narratology. Similitude and Differences between (Video)games and Narrative. Helsinki: Parnasso. №3, 365-371.

Esposito, N. (2005). A Short and Simple Definition of What a Video Game Is. Proceedings of DiGRA 2005 (Changing Views: Worlds in Play). Vancouver (Canada), 16-20 juin.

Sicart, M. (2009). The Ethics of Computer Games. Cambridge, MA: MIT Press.

Egenfeldt-Nielsen, S., Smith, J. H., \& Tosca, S. P. (2012). Understanding Video Games: The Essential Introduction (2nd ed.). Routledge, New York, NY.

Nardone, R. (2017). Videogames between ethics and politics, Ricerche di Pedagogia e Didattica. Journal of Theories and Research in Education. No. 12(2), 41-55, https://doi.org/10.6092/ issn. 1970-2221/7072

Huizinga, J. (1949). Homo Ludens: A Study of the Play-Element in Culture. London: Routledge \& Kegan Paul.

Leino, O. T. (2010). Emotions in play: On the constitution of emotions in solitary computer game play (PhD thesis). University of Copenhagen.

Wolf, M. J., \& Perron, B. (2014). The Routledge companion to video game studies. New York, NY: Routledge, Taylor \& Francis Group.

Juul, J. (2005). Half-real: Video Games between Real Rules and. Fictional Worlds. Cambridge MA: The MIT Press.

Bateman, C. (2011). Imaginary Games. Zero Books, John Hunt Publishing Ltd., Winchester, UK.

Bogost, I. (2008). The Rhetoric of Video Games. The Ecology of Games: Connecting Youth, Games, and Learning. Edited by Katie Salen. The John D. and Catherine T. MacArthur Foundation Series on Digital Media and Learning. Cambridge, MA: The MIT Press, 2008. 117-140. doi: 10.1162/dmal.9780262693646.117.

Sicart, M. (2011). Against Procedurality. Game Studies. vol. 11, no. 3. Retrieved from http://gamestudies.org/1103/articles/ sicart ap.

Salin, A. V. (2018). Principles of Procedural Hermeneutics. The Philosophy of Computer Games Conference. Copenhagen.

Aarseth, E. (2003). Playing Research: Methodological approaches to game analysis. In Proceedings of Digital Arts and Culture Conference (Melbourne, May 2003). DOI:10.7238/ a.v0i7.763

Arjoranta, J. (2011). Do We Need Real-Time Hermeneutics? Structures of Meaning in Games. Think Design Play: The Fifth International Conference of the Digital Games Research Association, Netherlands: DiGRA/Utrecht School of the Arts.

Fjællingsdal, K. (2014). Let's Graduate - A thematic analysis of the Let's Play phenomenon (Master thesis). Norwegian University of Science and Technology, Trondheim, Norway.

\section{LIST OF REFERENCES LINKS}

Bleicher J. Contemporary hermeneutics: Hermeneutics as method, philosophy, and critique. London: Routledge \& Kegan Paul, 1980. 288 p.

Palmer R. E. Hermeneutics: Interpretation Theory in Schleiermacher, Dilthey, Heidegger, and Gadamer. Northwestern University Press, 1969. $283 p$

Demeterio F.P.A. III. Introduction to Hermeneutics. Diwatao. 2001. 1(1). P. 1-9.

Gadamer H.-G. Truth and method. Second revised edition. Translation revised by Joel Weinsheimer and Donald g. Marshall. New York: Continuum, 2004. 601 p.

Jeanrond W. G. Theological Hermeneutics Development and Significance. Basingstoke; London: Macmillan, 1991. 220 p.

Hoy D. C. The critical circle: literature, history, and philosophical hermeneutics. Berkeley: University of California Press, 1978. 182 p.

Yolanda M. W. Procedural plot generation in videogames to extend the player's agency in narrative: Bachelor's thesis / Departament d'Enginyeria i Ciència dels Computadors, Universitat Jaume I, Castelló de la Plana, Valencia, Spain, 2016. 103 p.

Horban O., Maletska M. Basic approaches to the definition of the concept of "videogame" as an element of modern scientific discourse. Skhid. 2018. 3(155). P. 29-33. doi: http://dx.doi.org/ 10.21847/1728-9343.2018.3(155).139675.

Arjoranta J. Real-Time Hermeneutics Meaning-Making in Ludonarrative Digital Games: PhD thesis / The Department of art and Culture Studies, University of Jyväskylä, Jyväskylä, Finland, 2015. $105 \mathrm{p}$.

Bashova K., Pachovski V. Visual novel. Unpublished. DOI: https://doi.org/10.13140/RG.2.1.5007.6405 (Last accessed: 06.09.2019).

Frasca G. Ludology Meets Narratology. Similitude and Differences between (Video)games and Narrative. Helsinki: Parnasso. 1999. №3. P. 365-371

Esposito N. A Short and Simple Definition of What a Video Game Is. Proceedings of DiGRA 2005 (Changing Views: Worlds in Play). Vancouver (Canada), 16-20 juin., Canada, 2005.

Sicart M. The Ethics of Computer Games. Cambridge, MA: MIT Press, 2009. 264 p. 
Egenfeldt-Nielsen S., Smith J. H., \& Tosca S. P. Understanding Video Games: The Essential Introduction (2nd ed.). Routledge, New York, NY, 2012. 336 p.

Huizinga J. Homo Ludens: A Study of the Play-Element in Culture. London: Routledge \& Kegan Paul, 1949. 220 p.

Leino O. T. Emotions in play: On the constitution of emotions in solitary computer game play: PhD thesis / University of Copenhagen, 2010. 307 p.

Wolf M. J., Perron B. The Routledge companion to video game studies. New York, NY: Routledge, Taylor \& Francis Group, 2014. 544 p.

Juul J. Half-real: Video Games between Real Rules and. Fictional Worlds. Cambridge MA: The MIT Press, 2005. 255 p.

Bateman C. Imaginary Games. Zero Books, John Hunt Publishing Ltd., Winchester, UK. 2011. 311 p.

Bogost I. The Rhetoric of Video Games. The Ecology of Games: Connecting Youth, Games, and Learning / Edited by Katie
Salen. The John D. and Catherine T. MacArthur Foundation Series on Digital Media and Learning. Cambridge, MA: The MIT Press, 2008. P. 117-140. doi: 10.1162/dmal.9780262693646.117.

Sicart M. Against Procedurality. Game Studies. 2011. vol. 11. no. 3. URL: http://gamestudies.org/1103/articles/sicart_ap (Last accessed: 06.09.2019)

Salin A. V. Principles of Procedural Hermeneutics. The Philosophy of Computer Games Conference. Copenhagen, 2018. 8 p.

Aarseth E. Playing Research: Methodological approaches to game analysis. In Proceedings of Digital Arts and Culture Conference (Melbourne, May 2003). DOI: 10.7238/a.v0i7.763

Arjoranta J. Do We Need Real-Time Hermeneutics? Structures of Meaning in Games. Think Design Play: The Fifth International Conference of the Digital Games Research Association. Netherlands: DiGRA/Utrecht School of the Arts, 2011. $13 \mathrm{p}$.

Fjællingsdal K. Let's Graduate - A thematic analysis of the Let's Play phenomenon: Master thesis / Norwegian University of Science and Technology, Trondheim, Norway, 2014. 74 p.

Олександр Горбань,

Київський університет імені Бориса Грінченка (м. Київ, Україна)

e-mail: o.horban@kubg.edu.ua, ORCID 0000-0003-2321-5963

Марія Малецька,

Київський університет імені Бориса Грінченка (м. Київ, Украӥна)

e-mail:vernaya.lynx@gmail.com,ORCID 0000-0003-3123-9500

\section{ОСНОВНІ ГЕРМЕНЕВТИЧНІ ПІДХОДИ ДО ІНТЕРПРЕТАЦІЇВІДЕОІГОР}

Стаття присвячена інтерпретації відеоігор та основним герменевтичним підходам до інтерпретації відеоігор. Відеоігри - це складний сучасний феномен, який вирізняється серед інших медіа завдяки своїй інтерактивності та особливим взаємозв'язкам між гравцем та грою. Відсутність загальноприйнятої методології, зокрема герменевтичної, ускладнює інтерпретацію відеоігор та розуміння особливостей інтерпретації гравцем, глядачем та розробником ігор. У статті описані ключові концепти герменевтики, важливі для розв'язання поставлених завдань. У результаті авторами виділено чотири герменевтичні підходи на основі центральних концептів розуміння феномену відеогри: 1) герменевтика гри / загальна герменевтика - без особливого центрального концепту (відеогра інтерпретується без урахування її інтерактивності); 2) людо-герменевтика - на основі концепту гри (відеогра інтерпретується як гра, гра вбачається пріоритетнішою за гравця); 3) процедурна герменевтика - на основі правил як центрального концепту (відеогра інтерпретується як процедурна система; цей підхід не враховує важливість дій гравця та можливість порушувати правила гри); 4) герменевтика реального часу (ріал-тайм герменевтика) - на основі концепту інтерактивності (відеогра інтерпретується як інтерактивна система; цей підхід зазначає особливу роль гравця та відділяє їі від ролі глядача). Надано детальну характеристику зазначених підходів. Виокремлено можливість множинності інтерпретаторів відеоігор: не лише гравці, які інтерпретують гру з точки зору виграшу або досягнення власної мети, а й глядачі та розробники можуть інтерпретувати відеоігри у різний спосіб завдяки різниці позицій інтерпретаторів. Вони також можуть здійснювати взаємний вплив на інтерпретацію один одного. У статті відображено ті аспекти інтерпретації відеоігор, які не були охоплені наявними герменевтичними підходами.

Ключові слова: відеогра; герменевтика; людо-герменевтика; процедурна риторика; процедурна герменевтика; герменевтика реального часу; інтерпретація.

(c) Horban Olexandr, Maletska Maria

Надійшла до редакції: 09.09.2019

Прийнята до друку: 27.09.2019 